\title{
New genera and species of gall midges (Diptera, Cecidomyiidae) associated with Guarea macrophylla (Meliaceae)
}

\author{
Valéria Cid Maia \\ Departamento de Entomologia, Museu Nacional. Quinta da Boa Vista, São Cristóvão, 20940-040 Rio de Janeiro, \\ Rio de Janeiro, Brasil. E-mail: maiavcid@acd.ufri.br
}

\begin{abstract}
Three distinct leaf galls are recorded on Guarea macrophylla (Meliaceae). The galling species were identified as Neolasioptera sp., Guareamyia purpura gen. nov. and sp. nov.; Sphaeramyia flava gen. nov. and sp.nov. The new genera and species are described and illustrated based on material collected at restinga areas in Bertioga (São Paulo, Brazil).
\end{abstract}

KEY WORDS. Gall; restinga; taxonomy.

RESUMO. Novos gêneros e espécies de mosquitos galhadores (Diptera, Cecidomyiidae) associados com Guarea macrophylla (Meliaceae). Três galhas foliares distintas são registradas em Guarea macrophylla (Meliaceae). As espécies galhadoras foram identificadas como Neolasioptera sp., Guareamyia purpura gen. nov. e sp. nov.; Sphaeramyia flava gen. nov. e sp. nov. Os gêneros e espécies novas são descritos e ilustrados com base em material coletado em áreas de restinga em Bertioga (São Paulo, Brasil).

PALAVRAS-CHAVE. Galha; restinga; taxonomia.

Guarea macrophylla Vahl (Meliaceae) is commonly known as "saco de gambá", "pau d'arco", "camboatã" and "marinheiro". It is widespread in South America and has been recorded in Argentina, Bolivia, Brazil, Colombia, Ecuador, Paraguay, Peru, Suriname and Venezuela. In Brazil, it occurs in Amazonas, Pará and São Paulo.

Three leaf galls morphologically distinct were observed on Guarea macrophylla, all induced by gall midges (Cecidomyiidae). These galls are easily distinguishable. One of them is a fusiform, multichambered swelling on midvein, up to $10 \mathrm{~cm}$ long (Fig. 1). The two others are complex leaf galls. Both are globose, about $4 \mathrm{~mm}$ diameter, spongy and one-chambered, but they differ in color: purple (Fig. 2) or yellow (Fig. 3). One of them (the purple one) was studied at morphological and ontogenetic levels by Kraus et al. (1996).

The objective of this paper is to identify and describe the galling species associated with Guarea macrophylla.

\section{MATERIAL AND METHODS}

Gall collections were made monthly in Bertioga (São Paulo) over a period of 12 months, from April, 2004 to March, 2005. Bertioga $\left(23^{\circ} 51^{\prime} 14^{\prime \prime} \mathrm{S}, 46^{\circ} 08^{\prime} 20^{\prime \prime} \mathrm{W}\right)$ is a plain situated along the north coast of the State of São Paulo and comprises an area about $482 \mathrm{~km}^{2}$ of Atlantic Forest, being $85 \%$ a protected area. The climate is wet tropical with rainy summer and the annual average temperature is about $18-20^{\circ} \mathrm{C}$.
Collections were made at three different localities of Bertioga, namely: Itaguaré, Guaratuba and Fazenda Pinto. Samples of host plant with flowers and fruits were pressed and later identified by Dr. Magenta (Universidade Santa Cecília, Santos, São Paulo). Each kind of gall was photographed in field, using digital camera.

Samples of galled leaves were removed from the host plant, kept in labeled plastic bags and taken to the laboratory. To obtain adults and pupal exuviae, samples of each kind of gall were kept individually in plastic pots covered by a fine screening and layered at the bottom with damp cotton and checked daily.

Adults and pupal exuvia were preserved in $70 \%$ alcohol and later mounted on slides following the methodology of GaGNÉ (1994). The key of GaGNé (1994) was used to determine the genera of the gall midges.

\section{RESULTS}

The cecidomyiid that induces midvein galls on Guarea macrophylla belongs to probably a new species of Neolasioptera Felt, 1908, a catchall genus of Alycaulini. Few specimens were obtained: only two larvae and two females.

Examined material. BRAZIL, São Paulo: Bertioga, Itaguaré, 23.V.2004, V. Maia leg., 1 female; Fazenda Pinto, 14.XII.2004, V. Maia leg., 1 female and 1 larva; 27.V.2005, V. Maia leg. 1 larva.

The two other gall midges belong to new genera of Oligotrophini, which are described herein.

Revista Brasileira de Zoologia 24 (2): 449-456, junho 2007 


\section{Guareamyia gen. nov.}

Diagnosis. Adult: palpus 2-3 segmented; antenna with 15-16 cylindrical flagellomeres; R5 straitght and shorter than wing; M3 present, $\mathrm{Cu}$ forked; CuP present; tarsal claws onetoothed; empodium longer than bend in claws; male cercus, hypoproct, parameres and aedeagus conspicuously shorter than gonocoxites; male hypoproct bilobate; female cerci fused. Pupa: antennal horn well developed; prothoracic spiracle reduced; abdominal segments without dorsal spines.

Adult. Head: palpus 2-3 segmented; antenna with 15-16 cylindrical flagellomeres, flagellomeres 1 and 2 not connate, flagellomeres neck bare. Thorax: scutum without scales outside vicinity of setal rows; wing: R1 reaching $\mathrm{C}$ before wing midlength, R5 straitght and shorter than wing, Rs absent, M3 present, Cu forked; CuP pesent; tarsal claws long and one-toothed; empodium longer than bend in claws. Abdomen: male abdominal tergites 78 with only two basal trichoid sensilla as vestiture; male sternites 2-8 sclerotized and setose; male cercus, hypoproct, parameres and aedeagus conspicuously shorter than gonocoxites; male hypoproct sligthly bilobate; male cercus ovoid; female tergite 8 with scattered setae; ovipositor barely protrusible; female cerci fused.

Pupa. Head: antennal horn well developed; face without visible papillae. Thorax: prothoracic spiracle short. Abdomen: segments 2-8 without dorsal spines.

Larva unkown.

Type species. Guareamyia purpura sp. nov.

Etymology. Guareamyia is composed of Guarea (the generic name of the host plant) + myia .

\section{Guareamyia purpura sp. nov.}

Figs 4-21

Adult. Body length: $1.90-3.20 \mathrm{~mm}$ in male $(\mathrm{n}=5)$ (Tab. I); $1.75-2.60 \mathrm{~mm}$ in female $(\mathrm{n}=5)$ (Tab. I).

Head (Fig. 4). Eye facets circular, vertex without facets. Antenna with scape obconic, pedicel globose, 15-16 flagellomeres in both sexes; circunfila as two connected ring (Figs 5 and 6); male last flagellomere globose and shorter than the others (Fig. 7); female last flagellomere variable (elongate and longer than the precedent or shorter than the others) (Figs 8 and 9). Frontoclypeus with 50-60 setae. Labrum long-attenuate with three pairs of ventral sensory setae. Hypopharynx of same shape as labrum, with long, anteriorly directed lateral setulae. Labella elongate-convex, each with several lateral setae and two short sensory setae. Palpus with 2-3 setose segments in both sexes: basal segment obconic, longer and wider than the others; segment two globose or ovoid, segment three when present the shortest one, globose or ovoid (Figs 10-12).

Thorax. Anepimeron setose; other pleural sclerites asetose. Wing (Fig. 13): length: $2.4-1.50 \mathrm{~mm}$ in male $(\mathrm{n}=5)$ (Tab. I); $1.80-1.40 \mathrm{~mm}$ in female $(\mathrm{n}=4)$ (Tab.1). Tarsal claws curved beyond midlength, toothed; empodium longer than bend in claws (Fig. 14).

Revista Brasileira de Zoologia 24 (2): 449-456, junho 2007
Table I. Guareamyia purpura, adult length $(\mathrm{mm})$ of body and wing in both sexes.

\begin{tabular}{cccccc}
\hline \multirow{2}{*}{ Specimen } & \multicolumn{2}{c}{ Body } & & \multicolumn{2}{c}{ Wing } \\
\cline { 2 - 3 } \cline { 5 - 6 } \cline { 5 - 6 } & Male & Female & & Male & Female \\
\hline 1 & 3.20 & 3.40 & & 2.40 & 1.80 \\
2 & 2.40 & 2.60 & & 1.90 & 1.75 \\
3 & 2.15 & 2.50 & & 1.80 & - \\
4 & 2.00 & 2.40 & & 1.50 & 1.45 \\
5 & 1.90 & 1.75 & & 1.45 & 1.40 \\
\hline
\end{tabular}

Abdomen. Male (Fig. 15): tergites 1-6 rectangular more sclerotized caudally, with complete row of caudal setae, two basal trichoid sensilla, and elsewhere with scales; tergites 7 and 8 weakly sclerotized, with only two basal trichoid sensilla as vestiture; sternites 2-8 rectangular, with setae more abundant mesally, a complete row of caudal setae, two basal trichoid sensilla, and elsewhere with scales. Female (Fig. 16): tergites 1-7 rectangular with complete row of caudal setae, two basal trichoid sensilla, and elsewhere with scales; tergite 8 with scattered setae at distal 1/2; sternites 2-6 rectangular with setae more abundant mesally, a complete row of caudal setae, two basal trichoid sensilla, and elsewhere with scales; sternite 7 rectangular with setae more abundant mesally and caudally; sternite 8 not sclerotized. Male terminalia (Fig. 17): gonocoxites wide, not splayed, without mesobasal lobe; gonostylus strongly curved beyond midlength and tapered at distal 1/3; cercus oval and setose; hypoproct sligthly bilobed and shorter than the cerci; parameres shorter than hypoproct; aedeagus tapering gradually to apex. Ovipositor barely protrusible; cerci spherical, setose, with scattered setae (Fig. 18).

Pupa. Length: 1.9-2.40 mm ( $\mathrm{n}=10)$ (Tab. II). Head: antennal horn triangular with serrated margin measuring 0.28 0.35 of length $(\mathrm{n}=10)$ (Fig. 19) (Tab. II); cephalic setae 0.05$0.07 \mathrm{~mm}$ long $(\mathrm{n}=9)$ (Tab. II); facial papillae not visible; upper

Table II. Guareamyia purpura, pupa length $(\mathrm{mm})$ of body, antennal horn, cephalic seta and prothoracic spiracle ( $\mathrm{n}=10$ specimens).

\begin{tabular}{|c|c|c|c|c|}
\hline Specimen & Body & Antennal $\mathrm{h}$ & halic & racic spiracle \\
\hline 1 & 2.4 & 0.35 & 0.07 & 0.040 \\
\hline 2 & 2.2 & 0.35 & 0.07 & 0.040 \\
\hline 3 & 2.2 & 0.33 & 0.06 & 0.040 \\
\hline 4 & 2.1 & 0.31 & 0.06 & 0.040 \\
\hline 5 & 2.1 & 0.30 & 0.06 & 0.040 \\
\hline 6 & 2.1 & 0.30 & 0.06 & 0.035 \\
\hline 7 & 2.0 & 0.30 & 0.06 & 0.030 \\
\hline 8 & 2.0 & 0.30 & 0.06 & 0.030 \\
\hline 9 & 1.9 & 0.28 & 0.05 & 0.030 \\
\hline 10 & 1.9 & 0.28 & - & 0.030 \\
\hline
\end{tabular}



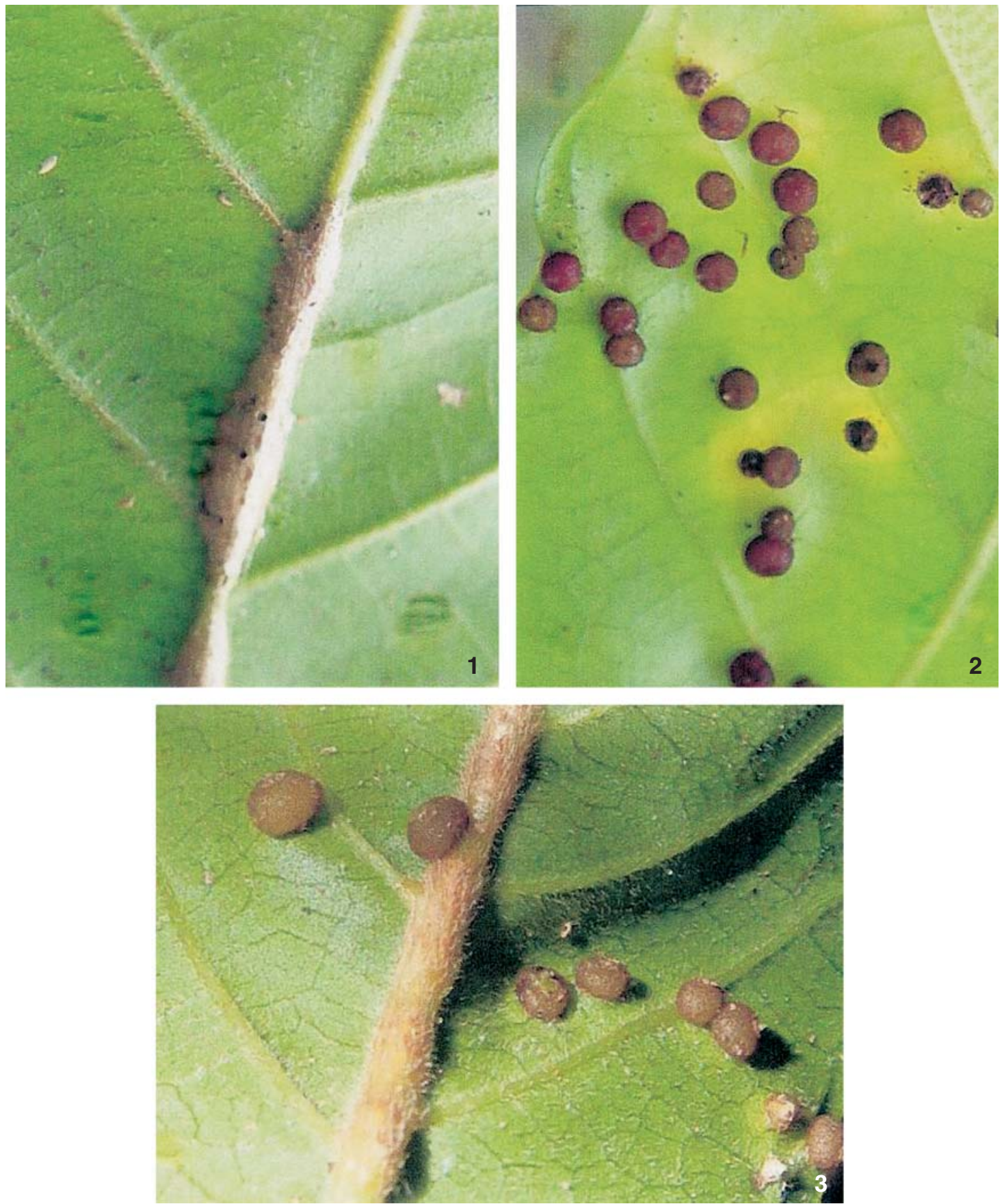

Figures 1-3. Leaf galls on Guarea macrophylla: (1) midvein gall; (2) purple globose gall; (3) yellow globose gall.

cephalic margin thickened laterally. Thorax: prothoracic spiracle short with 0.03-0.04 $\mathrm{mm}$ in length $(\mathrm{n}=10)$ (Fig. 20) (Tab. II); wing sheath reaching $1 / 2$ of abdominal segment 4 ; foreleg sheath reaching $1 / 2$ of abdominal segment 7 ; midleg sheath reaching distal margin of abdominal segment 7; hindleg sheath reaching distal margin of abdominal segment 8. Abdomen: segments 2-8 without dorsal; integument with sculptures (Fig. 21). Larva unknown.

Gall. Globose (diameter: $4 \mathrm{~mm}$ ), purple, one-chambered, on leaves.

Revista Brasileira de Zoologia 24 (2): 449-456, junho 2007 

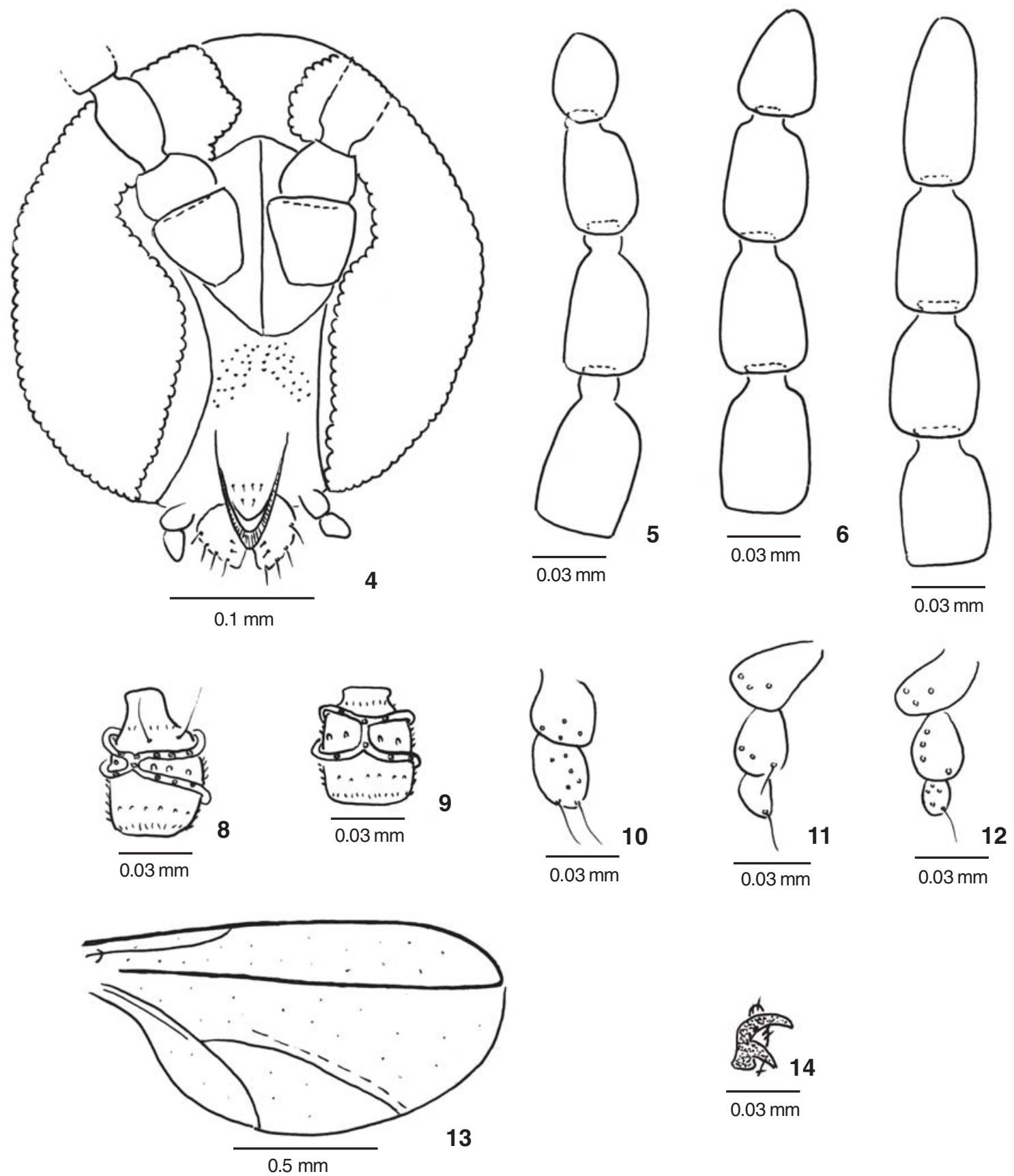

Figures 4-14. Guareamyia purpura sp. nov.: (4) head (frontal); (5) male flagellomere 5; (6) female flagellomere 5; (7) male last flagellomeres; (8) female last flagellomeres; (9) female last flagellomeres; (10) male palpus; (11) male palpus; (12) male palpus; (13) female wing; (14) female midleg, tarsal claw and empodium.

Type material. Holotype male. BRaziL, São Paulo: Bertioga, Itaguaré, 16.XI.2004, V. Maia leg. MNRJ. Paratypes: same data as holotype, 5 males, 4 females and 10 pupal exuviae.

Etymology. The name purpura refers to the color of the gall.

\section{Sphaeramyia gen. nov.}

Diagnosis. Adult: palpus 2-segmented; R5 straitght and shorter than wing; M3 absent, $\mathrm{Cu}$ forked; CuP absent; tarsal claws one-toothed; empodium longer than bend in claws; male

Revista Brasileira de Zoologia 24 (2): 449-456, junho 2007 

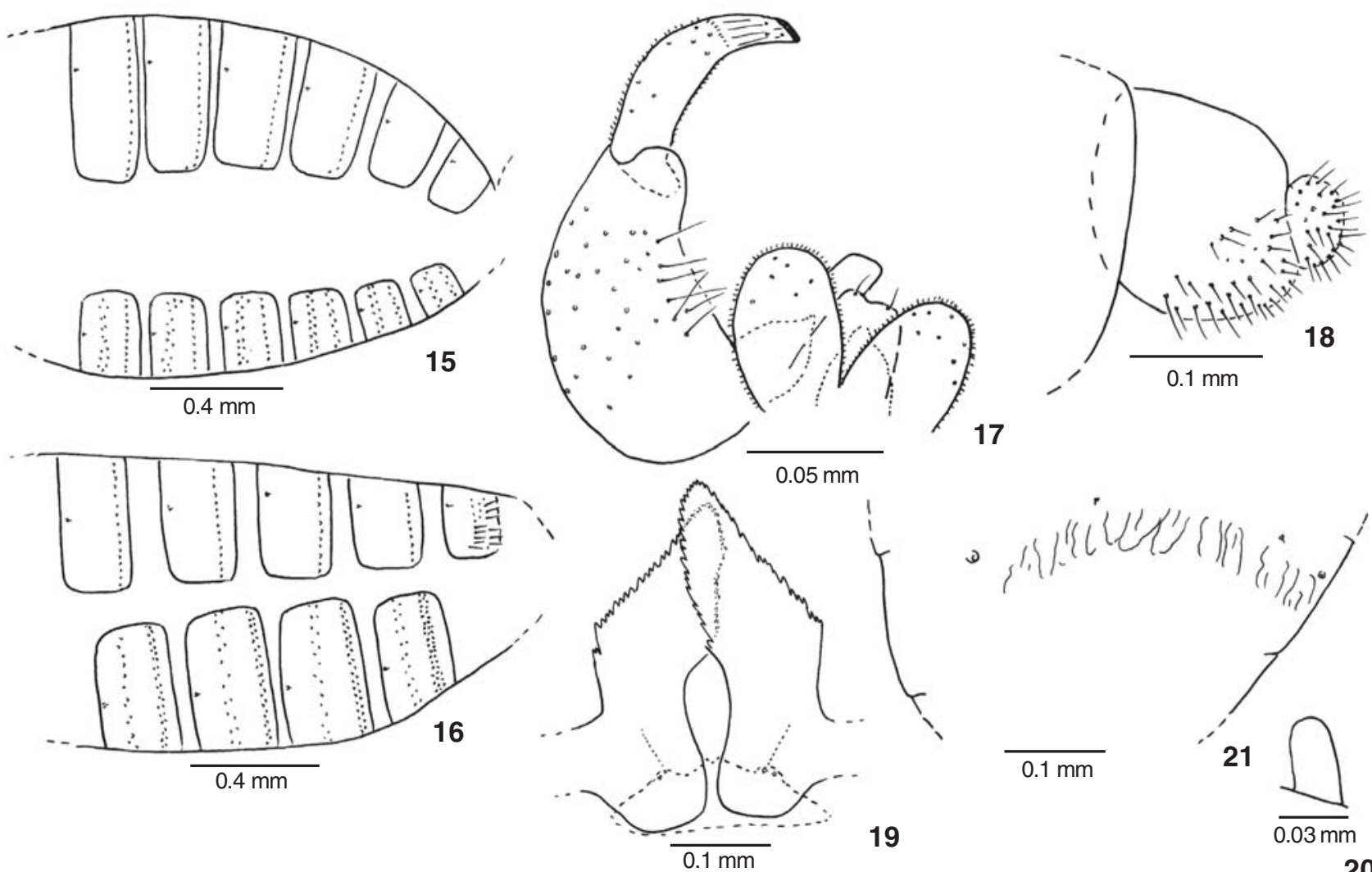

Figures 15-21. Guareamyia purpura sp. nov.: (15) male abdominal segments 3-8 (lateral); (16) female abdominal segments 4-8 (lateral); (17) male terminalia (dorsal); (18) female cercus (lateral); (19) pupa, antennal horn and cephalic seta; (20) pupa, prothoracic spiracle; (21) pupa, abdominal segment 7.

cercus, hypoproct and aedeagus conspicuously longer than gonocoxites; parameres shorter than gonocoxites; male hypoproct simple; female cerci fused. Pupa: antennal horn well developed; prothoracic spiracle reduced; abdominal segments without dorsal spines.

Adult. Head: palpus 2-segmented; antenna: flagellomeres 1 and 2 not connate, flagellomeres neck bare. Thorax: scutum without scales outside vicinity of setal rows; wing: R1 reaching $\mathrm{C}$ before wing midlength, R5 straitght and shorter than wing, Rs absent, M3 absent, $\mathrm{Cu}$ forked; $\mathrm{CuP}$ absent; tarsal claws long and with one tooth; empodium longer than bend in claws. Abdomen: male abdominal tergite 7 linear withot setae, tergite 8 not sclerotized; male sternites 2-8 sclerotized; male cercus, hypoproct and aedeagus conspicuously longer than gonocoxites; parameres shorter than gonocoxites; male hypoproct simple; female tergites 1-7 more sclerotized caudally, tergite 8 as in male; female sternites 2-6 more sclerotized caudally and mesally; female sternite 8 not sclerotized; ovipositor barely protrusible; female cerci fused.

Pupa. Head: antennal horn well developed; face without visible papillae. Thorax: prothoracic spiracle short and slen- der, setiform. Abdomen: segments 2-8 without dorsal spines; terminal segment with two apical projections.

Larva. Spatula four-toothed, anal segment elongate with two terminal lobes.

Type species. Sphaeramyia flava sp. nov.

Etymology. Sphaeramyia is composed of sphaera (= sphere, from latin) and refers to the shape of the gall + myia

\section{Sphaeramyia flava sp. nov.}

Figs 22-36

Adult. Body length: $3.10 \mathrm{~mm}$ in male $(\mathrm{n}=1) ; 3.20 \mathrm{~mm}$ in female $(\mathrm{n}=1)$.

Head (Fig. 22). Eye facets circular, vertex without facets. Antenna with scape obconic, pedicel globose, circunfila as two connected rings (Figs 23 and 24). Number of flagellomeres unknown (antenna broken). Frontoclypeus with 48 setae. Labrum long-attenuate with three pairs of ventral sensory setae. Hypopharynx of same shape as labrum, with long, anteriorly directed lateral setulae. Labella elongate-convex, each with several lateral setae and two short sensory setae. Palpus with two

Revista Brasileira de Zoologia 24 (2): 449-456, junho 2007 


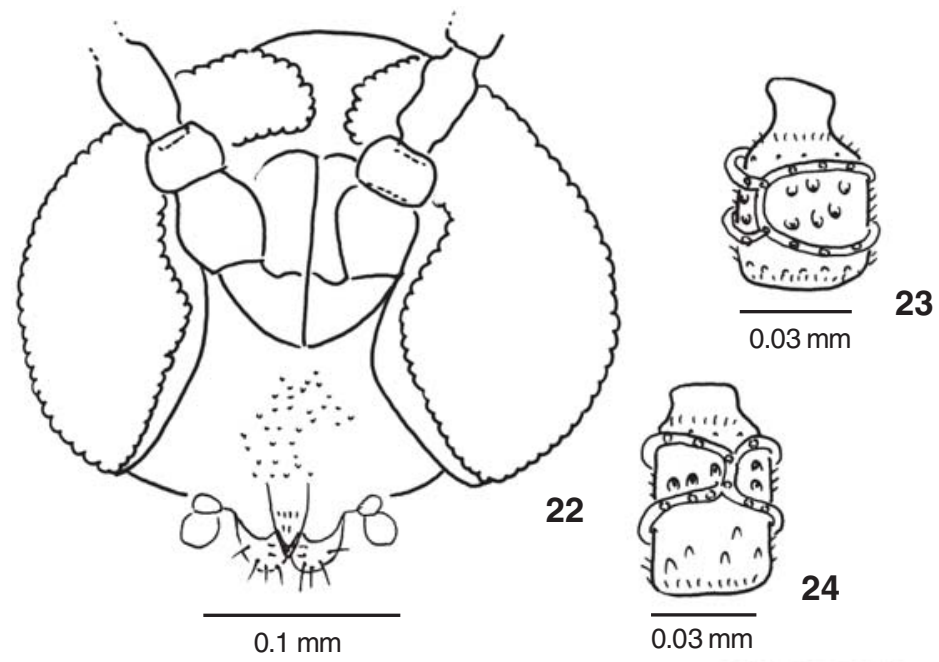

23
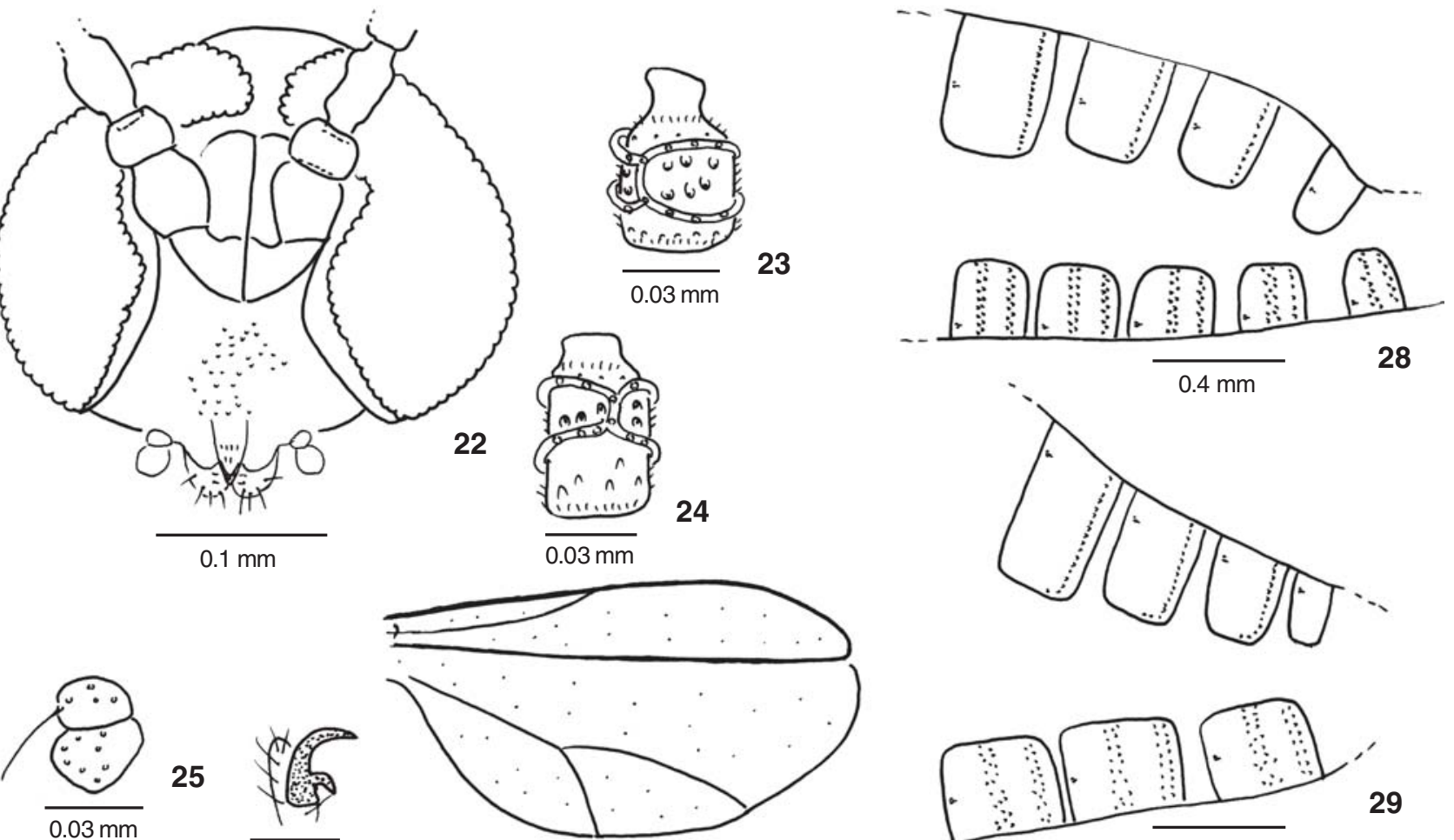

25
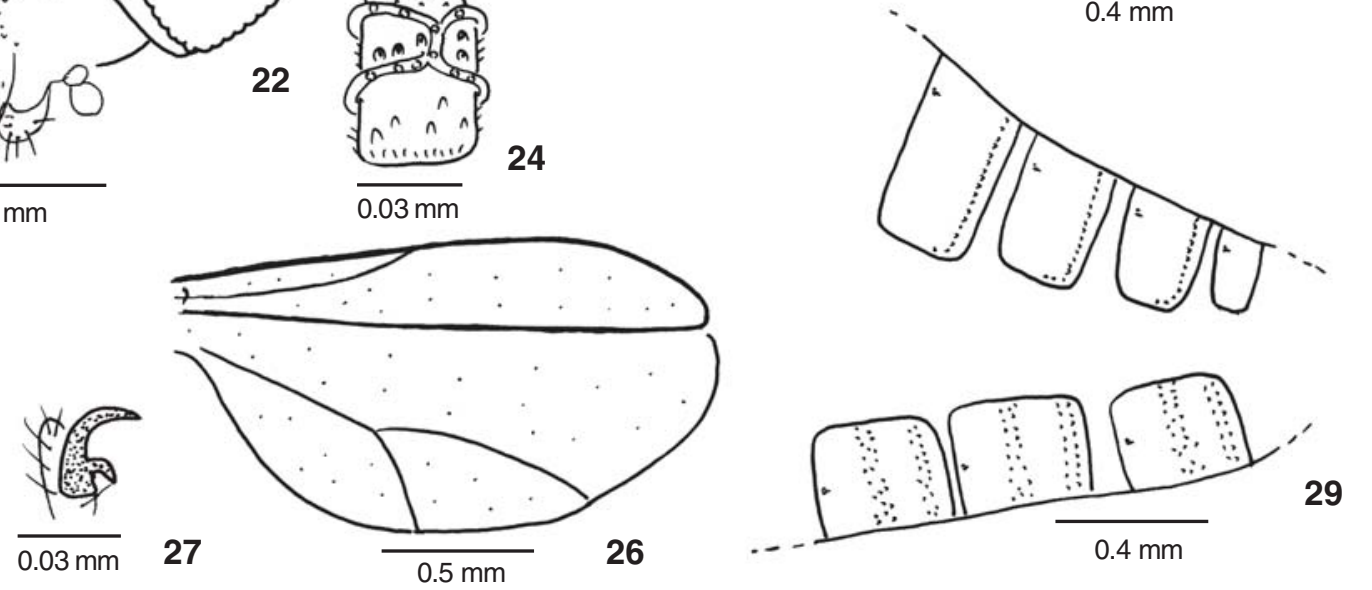

Figures 22-29. Sphaeramyia flava sp. nov.: (22) head (frontal); (23) male flagellomere 3; (24) female flagellomere 2; (25) male, palpus; (26) male wing; (27) female, midleg, tarsal claw and empodium; (28) male abdominal segments 4-8 (lateral); (29) female abdominal segments 5-8 (lateral).

globose and setose segments, the basal the longest and widest one (Fig. 25).

Thorax. Anepimeron setose; other pleural sclerites asetose. Wing (Fig. 26): length: $1.90 \mathrm{~mm}$ in male $(\mathrm{n}=1) ; 2.30$ $\mathrm{mm}$ in female $(\mathrm{n}=1)$. Tarsal claws curved near basal third, toothed; empodium longer than bend in claws (Fig. 27).

Abdomen. Male (Fig. 28): tergites 1-6 rectangular more sclerotized caudally, with complete row of caudal setae, two basal trichoid sensilla, and elsewhere with scales; tergites 7 linear with only two basal trichoid sensilla, tergite 8 not sclerotized with only two basal trichoid sensilla; sternites 2-8 rectangular, with setae more abundant mesally, a complete row of caudal setae, two basal trichoid sensilla, and elsewhere with scales. Female (Fig. 29): tergites 1-7 rectangular more sclerotized caudally, with complete row of caudal setae, two basal trichoid sensilla, and elsewhere with scales; tergite 8 as in male; sternites 2-6 rectangular more sclerotized caudally and mesally, sternites 2-7 with setae more abundant mesally, a complete row of caudal setae, two basal trichoid sensilla, and elsewhere with scales; sternite 8 not sclerotized. Male terminalia (Fig. 30): gonocoxites wide, not splayed, without mesobasal lobe; gonostylus slender, tapering gradually to apex, cercus ovoid and setose, barely longer than hypoproct; hypoproct simple and truncate at apex; parameres slender and short, aedeagus conspicuously longer than cercus, rounded at apex. Ovipositor barely protrusible; cerci ovoid, setose, with scattered setae (Fig. 31).

Pupa. Length: 3.1-3.6 mm $(\mathrm{n}=2)$. Head: antennal horn triangular with serrated margin measuring 0.26-0.34 $\mathrm{mm}$ of length $(\mathrm{n}=2)$ (Fig. 32); cephalic setae 0.25-0.27 mm long $(\mathrm{n}=$ 2); facial papillae not visible; upper cephalic margin thickened laterally. Thorax: prothoracic spiracle short with $0.08 \mathrm{~mm}$ in length $(n=2)$ (Fig. 33$)$; wing sheath reaching basal $1 / 3$ of abdominal segment 3 ; foreleg sheath reaching distal $1 / 5$ of abdominal segment 3 ; midleg sheath reaching $1 / 2$ of abdominal segment 4 ; hindleg sheath reaching distal $1 / 4$ of abdominal segment 4. Abdomen: segments 2-8 without dorsal.

Larva. Body cylindrical, conspicuously tapering to caudal end (Fig. 34); prothoracic spatula with four teeth not similar in length (Fig. 35); terminal segment with two lobes, each with one corniform papilla (Fig. 36).

Gall. Globose (diameter: $4 \mathrm{~mm}$ ), yellow, one-chambered, on leaves.

Revista Brasileira de Zoologia 24 (2): 449-456, junho 2007 


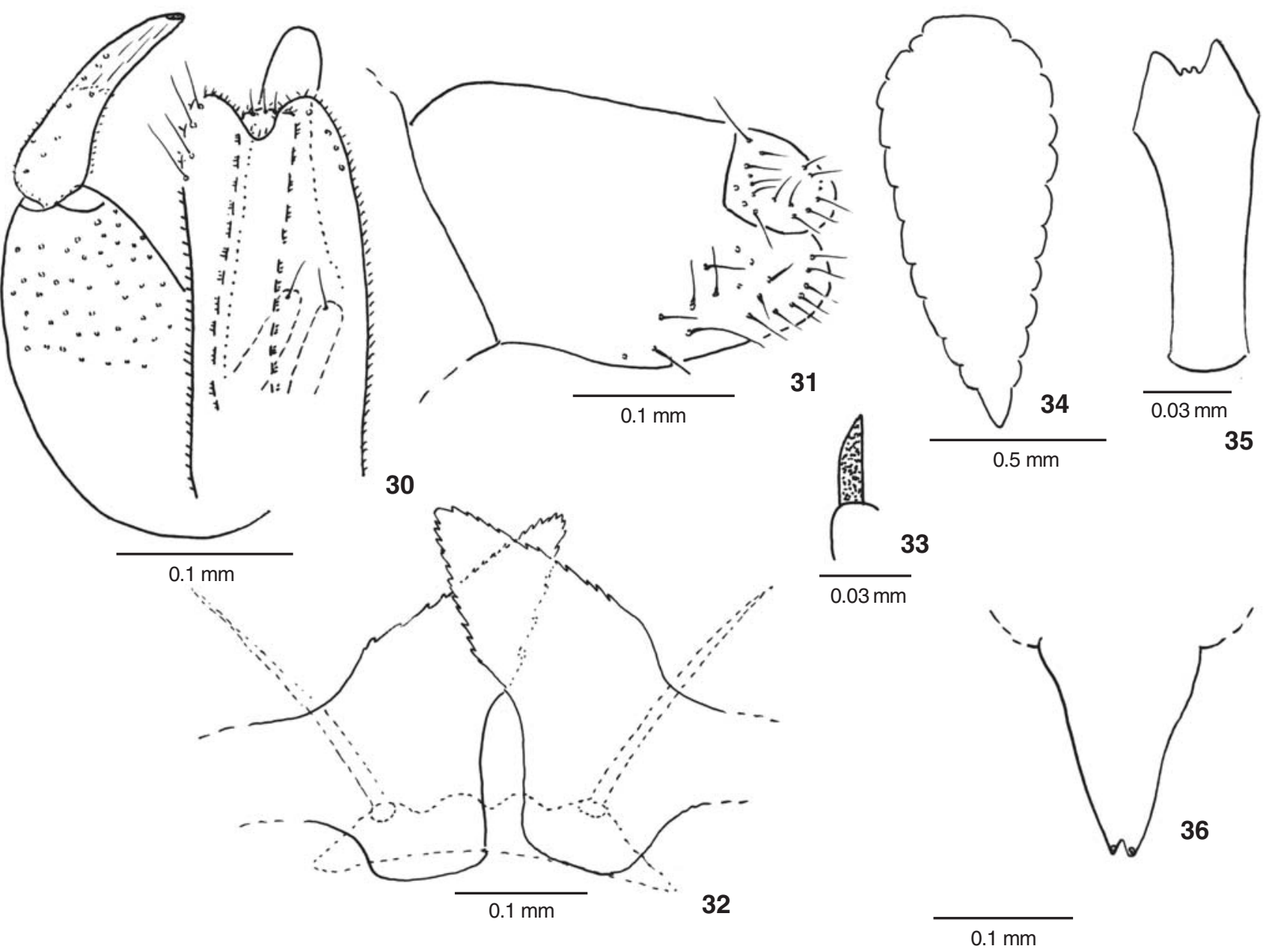

Figures 30-36. Sphaeramyia flava sp. nov.: (30) male terminalia (dorsal); (31) female cercus (lateral); (32) pupa, antennal horn and cephalic seta; (33) pupa, prothoracic spiracle; (34) larva, general aspect; (35) larva, prothoracic spatula; (36) larva, terminal segment.

Type material. Holotype male. BraziL, São Paulo: Bertioga, Fazenda Pinto, 26.VIII.2004, V. Maia leg. MNRJ. Paratypes: same data as holotype, 01 female, 2 pupal exuvia and 1 larva.

Etymology. The name flava (= yellow, from latin) refers to the color of the gall.

Comments. Guareamyia and Sphaeramyia belongs to Oligotrophini, a large and heterogeneous tribe of Lasipteridi. Both genera will not run past couplet 27 in GAGNÉ (1994), which leads to Calmonia Tavares, 1917 and Dasineura Rondani, 1840. Calmonia presents palpus one-segmented; parameres not clasping aedeagus; ovipositor elongate and protrusible; and female cerci separate and tiny. Dasineura presents palpus usually foursegmented; parameres clasping aedeagus; ovipositor elongate and protrusible; and female cerci fused. Otherwise, the new genera have palpus with two or three segments; parameres clasping aedeagus; ovipositor short, barely protrusible; and female cerci fused. Guareamyia differs from Sphaeramyia in the number of segments of the palpus (two or three in the former; two in the latter), in the wing venation (M3 and CuP present only in Guareamyia), in the chaetotaxy of the male tergite 7 (asetose in Guareamyia and setose in Sphaeramyia) and of the female tergite 8 (setose in Guareamyia and asetose in Sphaeramyia), in the relative length of male cercus, hypoproct and eadeagus (shorter than gonocoxites in Guareamyia and conspicuously longer in Sphaeramyia).

TAVARES (1909) described a new genus and species of gall midge that induces similar galls on the same genus of host plant: Guarea sp., possibly trichilioides from Rio Grande do Sul (Brazil). This species (Guarephila albida Tavares, 1909) also belongs to Oligotrophini, but differs from the new genera mainly in having palpus one-segmented; R5 as long as the wing and tarsal claws with two teeth.

Revista Brasileira de Zoologia 24 (2): 449-456, junho 2007 


\section{ACKNOWLEDGMENTS}

To Mara Magenta (Universidade Santa Cecília, São Paulo) for the host plant identification.

\section{REFERENCES}

GAGNÉ, R. J. 1994. The gall midges of the Neotropical region.
Ithaca, Cornell University, 352p.

Kraus, J.E.; H.C. Sugiura \& S. Cutrupi. 1996. Morfologia e Ontogenia em Galhas Entomógenas de Guarea macrophylla subsp. tubercullata (Meliaceae). Fitopatologia Brasileira 21 (3): 349356.

TAVARES, J.S. 1909. Contributio prima ad cognitionem cecidologiae Braziliae. Brotéria, Série Zoológica 8: 5-28.

Received in 30.XI.2006; accepted in 31.V.2007.

Revista Brasileira de Zoologia 24 (2): 449-456, junho 2007 